\title{
The Effect of Institutional Ownership and Managerial Ownership on Firm Value with Profitability as an Intervening Variable Listed on the Indonesia Sharia Stock Index
}

\author{
Sabdo Panggiring, Sutrisno
}

\begin{abstract}
This study examines the effect of managerial ownership, institutional ownership on firm value with profitability as a mediating variable and firm size as a control variable. The population in this study were all companies listed on the Indonesian Sharia Stock Index (ISSI) during the 2015-2019 period, with amount 196 companies. Sampling was done by the purposive sampling method. The data collection method is carried out by data documentation techniques which are historical data available in annual financial reports. The data analysis technique used panel regression analysis and path analysis to determine the effect of mediation.

The results showed that institutional ownership and managerial ownership did not have a significant effect on profitability (ROA). institutional ownership does not affect firm value (TQ), but in managerial ownership, it has a negative effect on firm value (TQ). Other results show that profitability (ROA) has a positive effect on firm value (TQ). In the path analysis test, profitability (ROA) is not able to mediate between institutional ownership and firm value (TQ), but profitability (ROA) can mediate between managerial ownership and Firm Value (TQ).
\end{abstract}

Index Terms-managerial ownership, institutional ownership, firm value, profitability, firm size

\section{INTRODUCTION}

Indonesia's economic potential is starting to be noticed internationally, as seen in the G-20 environment. In 2019, Indonesia ranked second in terms of economic growth. This is due to strong support from the central government to curb the dependence on raw commodity exports, while increasing the role of various industries in the economy. Initial Public Offering (IPO), also known as go-public, is made into a company to achieve its goal, namely by offering its shares to the public, so that it can enlarge the company to increase its capitalization value.

Corporate governance has an important role, because it can improve the long-term sustainability of the company and increase trust in stakeholders and shareholders. This is supported by research (Nazir and Afza, 2018) that corporate governance significantly and positively affects firm value which confirms the positive role of corporate governance in

Sabdo Panggiring, Master of Management Program, Indonesia Islamic University, Yogyakarta, Indonesia

Sutrisno, Department of Management, Indonesia Islamic University, Yogyakarta, Indonesia reducing agency conflict and increasing firm value.

The relationship of Institutional Ownership with firm value can be explained that institutional ownership has an important role in management monitoring because institutional ownership will increase optimal supervision. This is a positive signal for investors so that they will buy shares and the stock and increase its price, which has an impact on increasing the firm value. According to Thanatawee (2014), there is a positive relationship between institutional ownership and firm value. This result contradicts the research conducted by Kusumawati, Titisari, Siddi (2021) which states that institutional ownership has no effect on firm value.

The relationship between Managerial Ownership and firm value can be explained with agency theory, which states that shareholders as owners of the company delegate their authority to other parties, namely managers. However, authority will lead to conflicts that will an impact the corporate. One way to reduce conflicts between principals and agents can be done by increasing the managerial ownership of a company (Wiranata and Nugrahanti, 2013). Yusra, Hadya, Begawati, Istiqomah, Afriyeni \& Kurniasih (2019), Rusyda and Priantinah (2018) and Fahlenbrach and Stulz (2009) suggest that Managerial Ownership has a positive effect on firm value. This is different to Nurwahidah, Husnan, and Nugraha AP (2019) who suggest that managerial ownership has a negative effect on firm value.

The relationship between Institutional Ownership and profitability can be explained that institutional ownership has an important meaning in monitoring management, because institutional ownership can encourage more optimal supervision. A large proportion of institutional ownership can increase supervisory efforts by the institution so that it can hinder the opportunistic behavior of managers and can assist company decision making, so as to improve the company's financial performance as measured by ROA (Candradewi \& Sedana, 2016). These results contradict the research of Wiranata \& Nugrahanti (2013) which states that Institutional Ownership has no effect on company performance.

Institutional ownership can assist the company in overseeing the management of the company and can ensure that the company's management can manage the company 
assets properly so as to create high profitability. The higher the profitability firm value, the higher the net profit will be, this will be followed by an increase in firm value (Natasha and Maksum, 2019). According to Sutrisno and Sari (2020) profitability is able to make institutional ownership affect the firm value. This is different to Larosa, Erlina and Abubakar (2019), who found that profitability is not able to mediate the effect of institutional ownership on firm value.

Managerial Ownership relationship to profitability can be explained that the agency approach considers managerial ownership as an instrument or tool to reduce agency conflict. Managerial share ownership will require managers to always be careful in making decisions because the results of these decisions will have a direct impact on the shares owned by managers. The greater the proportion of managerial ownership in company shares, the better the company's performance (Candradewi \& Sedana, 2016).

Managerial Ownership relationship to firm value through profitability can be explained that managers are involved in the share ownership with the aim of encouraging managers to manage the company well, because managers will bear the consequences of decisions that will be taken, so managers will be more careful in making decisions. Companies with good governance can maximize profitability which will impact the firm value. According to Nurwahidah, Husnan, and Nugraha AP (2019) profitability is able to intervene or mediate managerial ownership towards firm value. This is different to Maryanto (2017), who finds that managerial ownership has no effect on firm value through profitability.

The object of this research is a company listed on the Indonesia Sharia Stock Index (ISSI) in 2015-2019, different from previous research which used companies listed on the Indonesia Stock Exchange (IDX). This study used the Panel Least Squares method.

\section{LITERATURE REVIEW AND DEVELOPMENT OF HYPOTHESIS}

\section{A. Firm Value}

Maximizing the firm value is very important for a company. This is because it can increase the prosperity of the owners and shareholders so that the company's goals can be achieved as previously expected. A high firm value will make investors interested in investing in the company. Before investors invest in shares in a company, they will make a stock valuation first based on the information they get from the capital market (Viriyah, Dhiana and Pranaditya, 2018).

\section{B. Ownership Structure}

Ownership structure is a comparison of the total shares owned by the company from within to the total shares owned by investors. The ownership structure is divided between managerial and institutional ownership. It can be concluded that the ownership structure includes a mechanism to reduce conflict between management and shareholders (Nuzuli, Diana, \& Mawardi, 2019).

Institutional ownership has an important role in corporate governance. This is very important in the supervision of managers because it will be able to increase more optimal supervision of managers. Such supervision can ensure the welfare of shareholders. In addition, high institutional ownership can lead to greater oversight by institutional investors on managers' opportunistic behavior (Hidayat et al., 2020).

Managerial ownership is one way to reduce agency problems, because managerial ownership is a tool for monitoring internal performance indicators. A large decrease in managerial ownership will not be able to align the interests of management and shareholders, so that the company's goal cannot achieve high profits, so managers tend not to own the company as a shareholder. Whenever that happens, performance achievement will not be reached and there will be a prolonged agency conflict (Nugroho, 2018).

\section{Profitability}

The company's profitability is the company's ability to generate net income from activities carried out in the accounting period. High profitability will provide an indication of good company prospects which will trigger investors to participate in increasing demand for shares. Furthermore, the increasing demand for shares will cause the firm value to increase (Prasetyorini, 2013).

\section{Hypothesis Development}

1) The effect instittuional ownership on profitability Institutional ownership is indicated by the high percentage of company shares owned by institutions. What is meant by institutional parties in this case are NGOs, insurance companies, banks, investment companies and private companies. Institutional ownership generally has a large proportion of ownership so that the monitoring process for managers is better. A high level of institutional ownership will lead to greater supervisory efforts by institutional investors so that it can hinder the opportunistic behavior of managers (Wiranata and Nugrahanti, 2013). This statement is supported by Larosa, Erlina and Abubakar (2019) who found that more institutional ownership owned by the company can increase management supervision so that management can manage the company well so that the company's profitability can increase. Institutional ownership increases management supervision for the management of the company, by reviewing profitability so that their objectives are met. Based on the explanation, the hypothesis in this study:

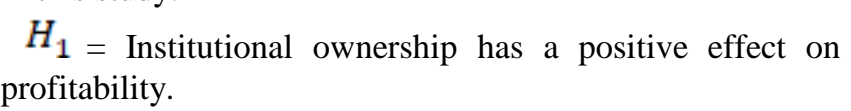

\section{2) The effect managerial ownership on profitability}

Higher managerial ownership in the company motivates managers to perform well because of the alignment of incentives. A manager who owns most of the shares in the company bears the consequences of managerial actions that create or destroy performance. As a consequence with shareholders, managers tend to work harder and make better investment decisions and companies with high managerial ownership must perform better (Din and Javid, 2011).

Managerial ownership (MO) is positively and significantly correlated with the performance (Q)/(ROA) of Sharia-compliant companies. Therefore, managerial ownership is considered as one of the main determinants of company performance in sharia-compliant companies. This 
result indicates that in the scenario of increasing the number of ownership in management, profitability will also increase. Managers, in this case, are working in a direction where owner managers can acquire targets aligning their interests as key stakeholders of the company (Katper et al., 2018). Based on the explanation, the proposed hypothesis in this study:

$H_{2}=$ Managerial ownership has a positive effect on profitability

3) The effect institutional ownership on firm value

There is a positive relationship between institutional ownership and firm value. When institutions are classified into domestic and foreign, it turns out that the firm value increases with higher ownership by domestic institutions, and worsens with higher ownership by foreign institutions. This finding has important implications regarding the relationship between institutional ownership and corporate governance. On the one hand, domestic institutional investors seem to be effective in providing monitoring activities, thereby reducing agency costs for free cash flow which tends to rise when there is a large excess of cash under the control of the managers (Thanatawee, 2014). Hasanudin, Nurwulandari, Adnyana \& Loviana (2020) stated that institutional ownership has a positive effect on firm value. Based on the explanation, the proposed hypothesis in this study:

$H_{3}=$ Institutional ownership has a positive effect on firm value.

4) The effect managerial ownership on firm value

Agency conflict is caused by the principals and agents having their own conflicts. Therefore, the agents and the principals seek to maximize each other's utility. The difference in interest between share ownership and fraudulent management can result in the loss of share ownership. Therefore, a control mechanism is needed to achieve balance. When that happens, management and share ownership have the motivation to increase the firm value. Share ownership is the proportion of common shares owned by management. Ownership of managers and shares will increase the firm value, so prosperity will also grow high. Increasing the proportion of shares owned by managers will reduce the tendency of managers to act excessively. Thus, it will unite the interests of managers and shareholders, this has a positive impact on increasing firm value. The greater the proportion of management's share ownership in the company, the more the management tends to try harder for the interests of shareholders who are none other than themselves (Nugroho, 2018).

A large increase in managerial ownership can lead to an increase in Tobin's q. Using insider trading data and the decomposition of changes in managerial ownership, the study shows that the positive relationship between a large increase in managerial ownership and a change in Tobin's q is driven by an increase in shares owned by officers rather than an increase in shares owned by directors or a change in the number of shares outstanding (Fahlenbrach). and Stulz, 2009).

The existence of Managerial Ownership in a company will lead to an interesting assumption that the Value of the Company increases as a result of the increase in Management Ownership. The higher the proportion of Managerial Ownership is, the more the managers will feel that they own the company, so he will try his best by taking actions that can maximize welfare (Rusyda and Priantinah, 2018). Based on the explanation, the hypothesis in this study:

$H_{4}=$ Managerial ownership has a positive effect on firm value.

5) The effect profitability on firm value

The company's financial performance is one indicator of the good and the bad of the effort to fulfill the responsibility of management to the principal to achieve the company's goals in the form of achievement. The results of this study are in line with agency theory which states that management's ability to manage assets to generate maximum profit can give shareholders confidence in the quality of good company management. The higher the company's financial performance is, the higher the firm value will be (Ilmi, Kustono and Sayekti, 2017).

High profitability reflects the company's ability to generate high profits for shareholders. A high profitability ratio owned by a company will attract investors to invest in the company. High ROE will increase stock prices, and will attract investors to invest their capital in the company. As such, there will be a positive relationship between profitability and stock prices where the high stock price will affect the firm value (Prasetyorini, 2013). Based on the explanation, the hypothesis in this study:

$H_{5}=$ Intellectual profitability has a positive effect on firm value.

6) The effect institutional ownership on firm value through profitability

Profitability is able to make institutional ownership to affect the firm value because if the profitability of the company increases, it will attract foundation or institutions to increase their share ownership, because if profitability is high, it is a sign for investors to invest. If the desire of investors is high for the company's shares, the share price will also increase and it will also affect the high firm value (Sutrisno and Sari, 2020).

Profitability serves as an intervening variable between institutional ownership and firm value. This is because institutional ownership can assist the company in overseeing the management of the company and can ensure that company management can manage company assets properly so as to create high profitability. The higher the profitability firm value is, the more the net profit will increase, this will be followed by an increase in firm value (Natasha, Maksum and Rujiman, 2019).

Hasanudin, Nurwulandari, Adnyana \& Loviana (2020) showed that company performance (ROE) is able to mediate the effect of institutional ownership on firm value. Based on the explanation, the hypothesis in this study:

$H_{6}=$ Profitability mediates the effect of relationship between institutional ownership on firm value.

7) The effect managerial ownership on firm value through profitability

Managerial ownership actually affects firm value, although the relationship does not appear to be monotonic. The positive impact of insider ownership towards firm value can be explained by the convergence of interest hypothesis, which states that large equity shares of insiders should be associated with higher market valuations due to lower agency costs (Din and Javid, 2011). 
Higher the company's profitability will increase the company's earnings per share. An increase in the company's earnings per share will make investors to be more interested in investing by buying company shares. Investors who buy the company shares will increase the company's share price and increase the firm value (Prasetyorini, 2013).

Financial performance shows the effectiveness of the company's operations and is used as a way to assess the success of the company's growth and performance related to firm value (Rusyda and Priantinah, 2018). According to Nurwahidah, Husnan, and Nugraha AP (2019) profitability is able to intervene or mediate managerial ownership towards firm value. Based on the explanation, the hypothesis in this study:

$H_{7}=$ Profitability mediates the effect of relationship between managerial ownership on firm value.

\section{RESEARCH METHODS}

The population in this study are all companies listed on the Indonesian Sharia Stock Index (ISSI) in 2015-2019. This study used purposive sampling or non-random sampling, by using an annual report to determine the samples. The sample criteria in this study are companies that publish an annual report and are registered with ISSI since 2015-2019 and have complete data on information about institutional ownership and managerial ownership.

The variables in this study is Firm Value (Y), Profitability (M), Institutional Ownership (X1), Managerial Ownership (X2) and the indicators from each that variables used:

\section{A. Dependent Variable: Firm Value}

Firm value in this study is used as an independent variable proxied by Tobin's Q. Tobin's $\mathrm{Q}$ is a ratio to measure the firm value, by comparing the market value of a company with the total assets of the company. Measurement of the market value of outstanding shares and debt. To measure Tobin's Q,

$$
\begin{aligned}
& T Q=\frac{M V E}{\text { Total Aset }} \\
& \text { Description: } \\
& \text { TQ }=\text { Tobin's Q } \\
& \text { MVE }=\text { Market value of all outstanding shares } \\
& \text { Debt }=\text { Total Debt } \\
& \text { TA }=\text { Total Activa }
\end{aligned}
$$

B. Intervening Variable: Profitability

Profitability is used in research as an intervening variable measured by Return on Assets (ROA). Profitability is the company's ability to generate profits by comparing net income after tax with total assets. Profitability is measured with the following formula:

$$
\begin{aligned}
& \text { ROA }=\frac{\text { EAT }}{\text { Total Assets }} \\
& \text { Description: } \\
& \text { EAT = Earning After Tax } \\
& \text { C. Independent Variables } \\
& \text { 1) Institutional Ownership }
\end{aligned}
$$

\section{1) Institutional Ownership}

Institutional share ownership is the shares owned by institutions such as NGOs, securities companies, pension funds, insurance companies, banks and investment companies (Wiranata and Nugrahanti, 2013). The way to measure institutional share ownership is by using the ratio of the number of shares owned by the institution to the number of shares outstanding. With the following measurements:

$$
\text { IOWN }=\frac{\text { Number of shares owned by institutional }}{\text { Number of shares outstanding year }}
$$

\section{2) Managerial Ownership}

Managerial ownership is the shares owned by the company's management, namely managers, commissioners, board of directors and parties directly involved in decision making. With the following measurements:

$$
\text { MOWN }=\frac{\text { Number of shares by the managerial }}{\text { Number of shares outstanding year }}
$$

\section{Control Variable: Firm Size}

Firm size is measured as the natural logarithm of the total book value of assets (LTA). Larger companies find it easier to generate funds internally and to gain access to funds from external sources, which can have a valuable effect on the company's performance $(\mathrm{Ng}$, 2005). The measurement formulas are as follows:

\section{LTA $=$ LN Total Assets}

Hypothesis testing regarding the effect institutional ownership and managerial ownership on firm value with profitability as a intervening variable uses the following equation:

$$
\begin{aligned}
& \mathrm{ROA}=\alpha_{1}+\beta_{1} \mathrm{IOwn}+\beta_{2} \mathrm{MOwn}+\beta_{3} \mathrm{LTA} \varepsilon \\
& T Q=\alpha_{2}+\beta_{4} I O w n+\beta_{5} \text { Mown }+\beta_{6} \text { ROA }+\varepsilon
\end{aligned}
$$

Figure 1 shows the conceptual framework of the study, the research hypothesis of this study:

Figure 1. Conceptual Framework

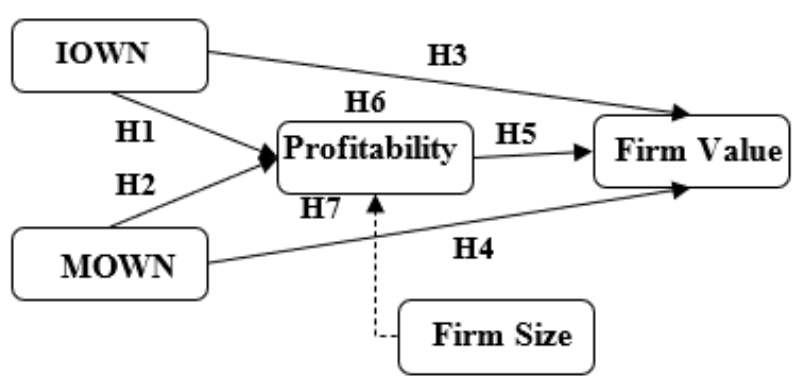

\section{RESULT AND DISCUSSION}

\section{A. Descriptive Statistic Analysis}

Descriptive analysis is a method used to analyze data by describing or depicting the data that has been collected as it is without intending to make conclusions that apply to the public or generalizations. Descriptive analysis technique explains the calculation of measures of central tendency such as mean, maximum, minimum and standard deviation.

In this study, Firm Value proxied by Tobin's Q (TQ) is used as the dependent variable, which is associated with several 
independent variables, namely Institutional Ownership (IOWN), Managerial Ownership (MOWN), Return on Assets (ROA) and Loan to Assets (LTA). The descriptive analysis in this study can be seen in the following table:

Table 1. Descriptive Statistic Analysis

\begin{tabular}{|l|c|c|c|c|c|}
\hline & TQ & IOWN & MOWN & ROA & LTA \\
\hline Mean & 1,108968 & 0,66259 & 0,043072 & 0,044677 & 12,34873 \\
\hline Median & 0,5995 & 0,6927 & 0 & 0,040421 & 12,41091 \\
\hline Maximum & 22,559 & 0,9964 & 0,732 & 0,457885 & 17,04706 \\
\hline Minimum & 0 & 0 & 0 & $-1,46526$ & 8,147883 \\
\hline Std. Dev. & 1,807108 & 0,216829 & 0,112969 & 0,105165 & 1,608489 \\
\hline Obs & 980 & 980 & 980 & 980 & 980 \\
\hline
\end{tabular}

Source: Output Eviews 10, 2021

Mean score of DER as of 0.7178 , maximum score as of 3.1287 owned by PT SAT Nusapersada Tbk in 2018. Minimum score as of 0.0010 owned by PT Nippon Indosari Corporindo in 2016. Mean score of VAIC as of 3.1546, maximum score as of 2.7713 owned by 13.5854 in 2014 owned by PT Astra International Tbk and minimum score as of -4.7108 owned by PT Keramika Indonesia Assosiasi Tbk in 2018 because this company suffered a loss. Mean score of ROA as of 0.0589 , maximum score as of 0.4666 owned by PT Unilever Tbk in 2018 and minimum score as of -0.4646 owned by PT Keramika Indonesia Assosiasi Tbk in 2018. Mean score of TQ as of 1.9465, maximum score as of 23.2857 owned by PT Unilever Tbk in 2017 and minimum score as of 0.2114 owned by PT Merck Tbk in 2018.

\section{B. Classic Assumsion Test}

The classical assumption test on the data has been freed from multicollinearity symptoms but there are heteroscedasticity symptoms which are then resolved using a robust standard error test.

\section{Selection Assumption Test}

The first step in selecting the estimation model is common effect regression. Next, the chow test was conducted to determine a better estimation model between the common effect or fixed effect, with the hypothesis that Ho chose the common effect estimate, while Ha chose the fixed effect estimate. If the probability result is $<0.05$, the better regression estimation model is the fixed effect model. Then, the Hausman test was carried out to determine a better regression estimation model between random effects or fixed effects, with the hypothesis that Ho chose a random effect estimate, while Ha chose a fixed effect estimate.

\section{Hypothesis Testing}

\section{1) $\mathrm{T}$ Test}

The test results of the selection of the selected regression model 1 is the Random Effect model. From the Table, it is known that the probability value for IOWN is 0.7134 and MOWN is 0.1239 when compared to alpha $5 \%$, it can be said that this result is not significant, which means that the variable IOWN, MOWN has no effect on ROA. While the control variable is LTA, the probability value is 0.0008 which is smaller than alpha $5 \%$ and the coefficient value is
0.011493 so that LTA has a positive effect on ROA. This is in line with previous research which shows firm size has a positive effect on ROA, which means, when company assets increase, management can generate greater profits (Janardhanan \& R, 2020). LTA variable can be used as a control variable on ROA because it can isolate the impact of other factors that affect company performance. Larger companies find it easier to generate funds internally and to gain access to funds from external sources, which can have a valuable effect on the company's performance ( $\mathrm{Ng}, 2005)$. Based on the results of the calculation of the Random Effect model, the following regression equation is obtained:

ROA $=-0,088525-0,00892610 \mathrm{WN}-0,065265 \mathrm{MOWN}+0,011493 \mathrm{LTA}+\varepsilon$ Table 2. Random Effect Model for Model 1

\begin{tabular}{|c|r|r|r|r|}
\hline \multicolumn{5}{|c|}{ Dependent Variable: TQ } \\
\hline Variable & Coefficient & $\begin{array}{r}\text { Std. } \\
\text { Error }\end{array}$ & t-Statistic & Prob. \\
\hline C & $-0,008926$ & 0,0243 & $-0,36736$ & 0,7134 \\
\hline DER & $-0,065265$ & 0.0424 & $-1,539888$ & 0,1239 \\
\hline VAIC & 0,011493 & 0.0034 & 3,365866 & 0,0008 \\
\hline ROA & $-0,088525$ & 0.0478 & $-1,853324$ & 0.0641 \\
\hline R-squared & \multicolumn{4}{|c}{0.0152} \\
\hline Adjusted & \multicolumn{4}{|c}{0,01222} \\
\hline R-squared & \multicolumn{4}{|c}{0.0019} \\
\hline Prob(F-statistic) & \multicolumn{4}{|c}{} \\
\hline
\end{tabular}

Source: Output Eviews 10, 2021

Then, the test results of the selection of the regression model of the selected model 2 is the Fixed Effect model. From the Table, it is known that the probability value for IOWN is 0.2425 when compared to alpha $5 \%$, it can be said that this result is not significant, which means that the IOWN variable has no effect on TQ. The MOWN variable shows a probability value of $0.0001<0.05$ and a coefficient value of -0.0925 . This means the MOWN variable has a negative effect on TQ. Meanwhile, the probability value of the ROA variable is $0.0000<0.05$ and the coefficient value is 0.6981 so it can be interpreted that ROA has a positive effect on TQ. Based on the calculation results of the Fixed Effect model, the following regression equation is obtained:

$T Q=1,0291+0,0795 I O W N-0,0925 M O W N+0,6981 R O A+\varepsilon$ Table 3. Fixed Effect Model for Model 2

\begin{tabular}{|c|c|c|c|c|}
\hline \multicolumn{5}{|c|}{ Dependent Variable: TQ } \\
\hline Variable & Coefficient & $\begin{array}{r}\text { Std. } \\
\text { Error }\end{array}$ & Statistic & Prob. \\
\hline IOWN & 0,0795 & 0,0679 & 1,1696 & 0,2425 \\
\hline MOWN & $-0,0925$ & 0,0239 & $-3,8665$ & 0,0001 \\
\hline ROA & 0,6981 & 0,1460 & 4,7803 & 0,0000 \\
\hline $\mathrm{C}$ & 1,0291 & 0,0464 & 22,1787 & 0,0000 \\
\hline R-squared & & & & 0.9457 \\
\hline \begin{tabular}{|l} 
Adjusted \\
R-squared \\
\end{tabular} & & & & 0,9319 \\
\hline Prob(F-statistic) & & & & 0.0000 \\
\hline
\end{tabular}

Source: Output Eviews 10, 2021

\section{2) Coefficient of Determination}

Model Random Effect Model 1 Table, Adjusted R-squared of $0.0122(10.22 \%)$ shows that IOWN, MOWN and LTA have a contribution in explaining the ROA variable of $10.22 \%$, while $89.78 \%$ is influenced by other variables outside the variable. this research. Robust Model Fixed 
Effect Model 2 Table, Adjusted R-squared of 0.9319 (93.19\%) shows that IOWN, MOWN and ROA have a contribution in explaining the TQ variable of $93.19 \%$. As the model chosen in this model 2 is Fixed Effect which is the Least Square Dummy Variable (LSDV), the Fixed Effect model generally has a relatively high R-Square because there are more explanatory variables. While the remaining $6.81 \%$ is influenced by other variables outside the variables of this study.

\section{E. Path Analysis}

The indirect effect of institutional ownership (IOWN) on firm value (TQ) through profitability (ROA) with a path coefficient value of -0.0062 , where this coefficient value is smaller than the coefficient of direct influence between institutional ownership (IOWN) on firm value. (TQ) is $-0.0062<0.0794$. This means that profitability is not able to mediate the influence between institutional ownership and firm value. Meanwhile, the indirect effect of managerial ownership (MOWN) on firm value (TQ) through profitability (ROA) has a path coefficient of -0.0455 , where the coefficient value is greater than the value of the direct influence coefficient, namely $-0.0455>-0.0924$, it can be interpreted that profitability is able to mediate the influence between managerial ownership and firm value.

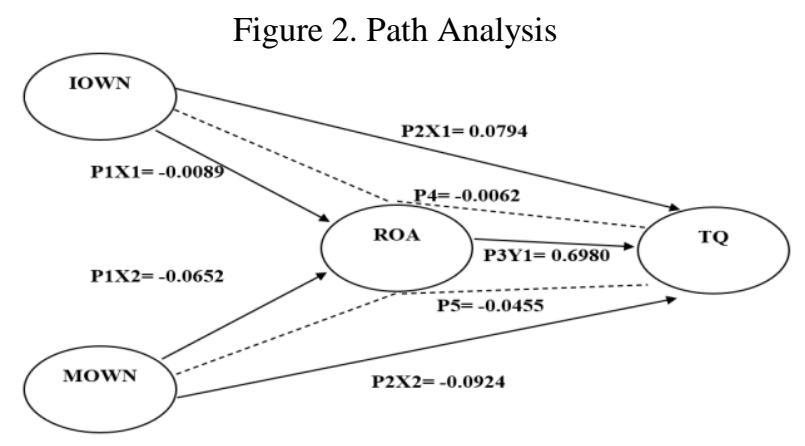

\section{F. Discussion}

\section{1) The effect institutional ownership on profitability}

The results shows that institutional ownership (IOWN) has no effect on profitability. The majority shareholders participate in controlling the company, resulting in an imbalance trend in determining the direction of company policy that only benefits the majority shareholders (Institutional ownership). Companies that are dominated by institutional investors will actually get a negative response by potential investors. This is because management is suspected of carrying out policies that are not appropriate and not trusted which raise the assumption that management tends to make decisions that only benefit the interests of institutional investors and ignore the interests of minority investors (Assaury Y \& Adriani, 2020).

The owners of the majority of institutions participate in controlling the company so they tend to act in their own interests. The existence of information asymmetry between shareholders and managers causes managers as company managers to be able to control the company because they have more information about the company than the shareholders. As such, institutional ownership does not guarantee that manager performance monitoring can run effectively and thus, does not affect the company's performance (Wiranata \& Nugrahanti, 2013). This is in line with the research of Sutrisno \& Sari (2020) which states that institutional ownership has no effect on profitability.

2) The effect of managerial ownership on profitability

The results shows that Managerial Ownership (MOWN) has no significant effect on profitability. The proportion of managerial ownership tends to be small, so the application of managerial ownership in helping to unite the interests between managerial and owner in order to improve performance has not been effective. This indicates that managerial ownership in the company is still not able to balance the interests of shareholders outside of management. This condition can lead to agency conflict and can trigger management to use their utility to seek their own profit, without thinking about the losses received by other shareholders. The large proportion of management's shares still cannot reduce agency conflicts within the company (Sutrisno \& Sari, 2020).

The proportion of managerial ownership that is too small causes the manager's performance to be less than optimal and the manager as a minority shareholder has not been able to actively participate in making a decision in the company, so it has no effect on the company's financial performance (Candradewi \& Sedana, 2016). This is in line with research conducted by Wiranata \& Nugrahanti (2013) which suggests that managerial ownership has no effect on the company's financial performance.

3) The effect of institutional ownership on firm value

The results shows that Institutional Ownership (IOWN) has no significant effect on firm value. Institutional ownership is the proportion of share ownership by institutional investors. Institutional investors are relatively weak in their supervision, so they are not able to make the company to increase its value (Setiyawati, Wahyudi \& Mawardi, 2017). Most of the company's institutional ownership is concentrated in one or more companies, so that the supervisory function of management performance is not optimal, there is a tendency to experience conflict of interest problems (Samasta, Muharam \& Haryanto, 2018).

Institutions cannot effectively monitor management. This can happen because of the information asymmetry between shareholders and management, so that management can control the company according to their wishes. This information asymmetry is an obstacle for institutions in monitoring management behavior, because the information held by the institution is not as good as the information held by management, so that the institution has difficulty controlling management behavior. As such, institutional ownership has no impact on firm value (Sutrisno \& Sari, 2020). This is in line with the research results of Kusumawati, et al (2021) which states that institutional ownership has no effect on firm value.

4) The effect managerial ownership on firm value

The result shows that Managerial Ownership (MOWN) has a significant negative effect on firm value. The existence of information asymmetry between the company's management and outside parties allows for high transaction costs for outside parties. The inclusion of management as a shareholder of the company is believed to reduce the risk of outsiders because management often bears the burden of the firm value. The decline in firm value is caused by 
opportunistic actions taken by managerial shareholders. Managerial ownership wanted high income, compared to investment growth in the company, so if managerial ownership is high, then the market tends to react negatively which causes the firm value to decrease (Wajdi \& Mayangsari, 2019). This is in line with the research by Nurwahidah, Husnan, and Nugraha AP (2019) which states that managerial ownership has a negative effect on firm value.

5) The effect profitability on firm value

ROA as a variable that states the profitability of the company, has a significant positive effect on the firm value. This shows that an action taken by the company's management to provide instructions for investors responds positively to the prospects of a company. If the profitability value is positive or influential, then this means that the company is able to use its assets productively to generate large profits (Kusumawati, et al, 2021). High profitability will provide an indication of good company prospects which will trigger investors to participate in increasing demand for shares. Furthermore, the increasing demand for shares will cause the firm value to increase (Prasetyorini, 2013).

The company's financial performance is one of the benchmarks for the existence and viability of the company. The company's ability to improve financial performance becomes a reference for investors to determine investment by buying company shares. Improving the company's financial performance is a must so that the company's shares remain attractive to investors. When investors assess the company's financial performance well, the firm value can also increase (Ilmi, Kustono and Sayekti, 2017). This is in line with research by Diana (2020) which finds that profitability has a positive effect on firm value.

\section{6) The effect institutional ownership on firm value} through profitability

The calculation result shows that the indirect coefficient value is smaller than the direct coefficient value. This means that profitability as an intervening variable is not able to mediate the influence between institutional ownership and firm value. Profitability is not able to mediate the effect of institutional ownership on firm value. Institutional ownership only oversees the actions of management for operational activities with the intention of attracting investors because of good operational activities. The amount of supervision will give investors an idea that the company will be able to grow rapidly. As such, the amount of institutional ownership is not to increase profits, but to attract the firm value where the investors are. So, profitability cannot act as an intervening variable (Larosa, Erlina and Abubakar, 2019).

This is in line with the research by Assaury Y \& Adriani (2020) which finds that profitability is not able to mediate the effect of institutional ownership on firm value, namely the inability of the return on assets variable to mediate the effect of institutional ownership on firm value. profit, so that the profits obtained are not able to attract investors to invest their capital.

7) The effect managerial ownership on firm value through profitability

The calculation result shows that the indirect coefficient value is greater than the direct coefficient value. This means that profitability as an intervening variable is able to mediate the influence between managerial ownership and firm value. Managers are involved in share ownership with the aim of encouraging managers to manage the company well, because managers will bear the consequences of decisions taken, so managers will be more careful in making decisions. In this case, managerial ownership is the manager who has share ownership in the company he manages. Companies with good governance can maximize profitability which will impact the firm value.

Managerial ownership actually affects firm value, although the relationship does not appear to be monotonic. The positive impact of insider ownership towards firm value can be explained by the convergence of interest hypothesis, which states that large equity shares of insiders should be associated with higher market valuations due to lower agency costs (Din and Javid, 2011).

Managerial ownership becomes the party that unites the interests of managers and investors. The greater the number of management shareholdings is, the better the manager's actions as company owners in managing the company will be. If there are wrong decisions and policies, management will also bear the consequences. The large proportion of managerial ownership makes management to tend to try to increase company profits for the benefit of investors and their own interests. This is an attraction for investors to invest their capital (Astutik, 2021), so that the firm value can increase. This is in line with the research of Nurwahidah, Husnan, and Nugraha AP (2019) which states that profitability is able to intervene or mediate managerial ownership on the value of

\section{CONCLUTION}

Institutional Ownership (IOWN) has no effect on Profitability (ROA). The owners of the majority of institutions participate in controlling the company so they tend to act in their own interests

Managerial Ownership (MOWN) does not have a significant effect on Profitability (ROA). The proportion of managerial ownership that is too small leads to less-than-optimal manager performance, and managers as minority shareholders have not been able to actively participate in making decisions in the company.

Institutional Ownership (IOWN) does not have a significant effect on Firm Value. Institutional investors are not effective in their supervision, because of the information asymmetry between shareholders and management in which the management can control the company according to their wishes.

Managerial Ownership (MOWN) has a negative and significant effect on Firm Value. Managerial ownership wants high income, compared to investment growth in the company, so if managerial ownership is high then the market tends to react negatively which causes a decrease in firm value.

Profitability (ROA) has a significant positive effect on firm value. If profitability is high, it will give an indication of good company prospects so that it can trigger investors to participate in increasing demand for shares

Profitability is not able to mediate the effect of institutional ownership (IOWN) on firm value. Institutional 
ownership only oversees the actions of management for operational activities with the intention of attracting investors because of good operational activities. Profitability is not able to mediate the effect of institutional ownership (IOWN) on firm value.

Profitability is able to mediate the effect of managerial ownership (MOWN) on firm value. Managerial ownership aims to encourage managers to manage the company well, so managers will be more careful in making decisions. Companies with good governance can maximize profitability which will impact the firm value.

\section{RESEARCH IMPLICATIONS}

It is hoped that this research will be useful as an input and general considerations for companies in improving the quality and policies of financial management through the influence of institutional ownership and managerial ownership on firm value with profitability as an intervening variable. So that the company can maximize the firm value with the expected profit with the optimal proportion of capital ownership structure. With optimal proportions, the management of the company can be carried out properly and responsibly, thereby increasing the trust of investors. This is expected to provide information as considerations for decision making in choosing a company that is in accordance with the expected firm value. This study can be an additional reference for research in the field of financial management regarding the influence of institutional ownership and managerial ownership on firm value with profitability as an intervening variable, because there have not been many similar studies with diverse respondents.

\section{LIMITATION AND RECOMMENDATIONS}

In this study, Tobin's $Q$ is used to measure the firm value variable. Another proxy can be used in further studies, namely PBV (Price to Book Value). For the measurement of profitability as an intervening variable using the ROA (Return on Asset) proxy. For further research, intervening variables can be modified with other proxies ROE or ROI to get more complete results.

\section{REFERENCES}

[1] Ahm Assaury Y, A. M. S., \& Adriani. (2020). Pengaruh Kepemilikan Institusional terhadap Nilai Perusahaan dengan Profitabilitas Sebagai Variabel Intervening pada Sektor Basic Industry \& Chemicals yang Terdaftar di Bursa Efek Indonesia Periode 2014-2019. Jurnal Aplikasi Manajemen, Ekonomi dan Bisnis. Vol. 5, No.1, 60 - 66. ISSN 2541-1438; E-ISSN 2550-0783

[2] Astutik, E. M. (2021). Faktor-Faktor Yang Memengaruhi Nilai Perusahaan Dengan Profitabilitas Sebagai Variabel Mediasi Pada Sektor Pertambangan Di Bei Tahun 2015-2018. Jurnal Ilmu Manajemen. Volume 9 Nomor 1. $264-280$.

[3] Candradewi, I., \& Sedana, I. B. P. (2016). Pengaruh Kepemilikan Manajerial, Kepemilikan Institusional Dan Dewan Komisaris Independen Terhadap Return on Asset. E-Jurnal Manajemen Unud, Vol. 5, No. 5, 2016: 3163 - 3190. ISSN : 2302-8912

[4] Diana, E. (2020). Examining the Factors Affecting Firm Values : The Case of Listed Manufacturing Companies In Indonesia. Journal of Accounting Research, Organization and Economics. Vol. 3 (1), 2020: $62-72$

[5] Din, S. and Javid, A. (2011).Impact of managerial ownership on financial policies and the firm's performance: evidence Pakistani manufacturing firms. Published in: International Research Journal of Finance and Economics No. 81 (2011): pp. 13-29.

[6] Fahlenbrach, R. and Stulz, R. (2009).Managerial Ownership Dynamics And Firm Value. Journal of Financial Economics 92 (2009) 342-361.

[7] Hasanudin, Nurwulandari, A., Adnyana, M., \& Loviana, N. (2020). The Effect of Ownership and Financial Performance on Firm Value of Oil and Gas Mining Companies in Indonesia. International Journal of Energy Economics and Polocy. 10(5), 103-109.

[8] Hidayat, R. et al. (2020) 'Institutional Ownership, Productivity Sustainable Investment Based on Financial Constrains and Firm Value: Implications of Agency Theory, Signaling Theory, and Asymmetry Information on Sharia Companies in Indonesia', International Journal of Financial Research, 11(1), p. 71. doi: 10.5430/ijfr.v11n1p71.

[9] Ilmi, M., Kustono, A. S. and Sayekti, Y. (2017) Effect Of Good Corporate Governance, Corporate Social Responsibility Disclosure And Managerial Ownership To The Corporate Value With Financial Performance As Intervening Variables: Case On Indonesia Stock Exchange .International Journal of Social Science and Business. Vol.1 (2) pp. 75-88

[10] Janardhanan, A. K., \& R, Uma V. (2020). The Role of Internal Control and Firm-Specific Characteristics on Firm Value: Evidence from Indian Financial Services Sector. Indian Journal of Finance and Banking; Vol. 4, No. 1, 117 - 133. ISSN 2574-6081 E-ISSN 2574-609X

[11] Katper, N. K., Shaikh, S. S., Anand, V., Ali, N. I. (2018). Analysing the Impact of Managerial Ownership on the Performance of Shariah-Compliant Firms in Pakistan. International Business Research; Vol. 11, No. 11; 2018. ISSN 1913-9004 E-ISSN 1913-9012

[12] Kusumawati, H. W., Titisari, K. H., Siddi, P. (2021). The Influence of Profitability, Leverage, Dividend Policy, Liquidity and Institutional Ownership on Firm Value LQ45. Journal of Indonesian Science Economic Research (JISER). Vol 3, No 1, February 2021 ISSN 2686-0074 (online)

[13] s Larosa, S. E., Erlina and Abubakar, E. (2019).Analysis Of The Factors Affecting Company Value With Profitability As Intervening Variables In Non Financial Companies Listed In Indonesia Stock Exchange 2015-2017 Period. International Journal of Public Budgeting, Accounting and Finance, 2(2), 1-15.

[14] Maryanto, H. K. (2017). Pengaruh Intellectual Capital Dan Good Corporate Governance Terhadap Nilai Perusahaan Dengan Kinerja Keuangan Sebagai Variabel Intervening Pada Perusahaan Manufaktur Di Bursa Efek Indonesia Tahun 2011-2014. JOM Fekon. Vol. 4 No. 1

[15] Natasha, S. E., Maksum, A. and Rujiman (2019).Analysis Of Factors Affecting Firm Value With Profitability As Intervening Variables In Manufacturing Companies Listed In Indonesia Stock Exchange In 2015-2017. International Journal of Public Budgeting, Accounting and Finance, 2(2), 1-12.

[16] Nazir, M. S. and Afza, T. (2018) 'Does managerial behavior of managing earnings mitigate the relationship between corporate governance and firm value? Evidence from an emerging market', Future Business Journal, 4(1), pp. 139-156. doi: 10.1016/j.fbj.2018.03.001.

[17] Ng, C. Y. M. (2005). An Empirical Study on the Relationship between Ownership and Performance in a Family-Based Corporate Environment. Journal of Accounting, Auditing \& Finance, 20(2), 121-146. doi:10.1177/0148558x0502000202

[18] Nugroho, D. M. (2018) The Relationship of Share Ownership, Economic Macro and Company Value Profitability As Mediation Variable(Case Study At Mining Industry Who are Listed in Bursa Efek Indonesia (BEI). International Journal of Research in Humanities and Social Studies. Volume 5, Issue 5, 2018, PP 1-9. ISSN 2394-6288 (Print) \& ISSN 2394-6296 (Online)

[19] Nurwahidah, Husnan, L. H., Nugraha AP, I. N. (2019). Pengaruh Kepemilikan Manajerial Terhadap Nilai Perusahaan Dengan Struktur Modal Dan Profitabilitas Sebagai Variabel Intervening Pada Perusahaan Real Estate Di Bursa Efek Indonesia. JMM UNRAM, 8(4),363- 377

[20] Nuzuli, Z. M., Diana, N., Mawardi, M. C. (2019). Pengaruh Struktur Kepemilikan Dan Special Purpose Entity (Spe) Terhadap Manajemen Laba Bagi Regulator Pasar Modal. E-JRA. Vol. 08 No. 02

[21] Prasetyorini, B. F. (2013).Pengaruh Ukuran Perusahaan, Leverage, Price Earning Ratio Dan Profitabilitas Terhadap Nilai Perusahaan. Jurnal Imu Manajemen. Volume 1 Nomor 1.

[22] Rusyda, Z. T. and Priantinah, D. (2018).The Effect Of Ownership Structure And Sustainability Report Disclosure Toward Company Value With Financial Performance As Intervening Variable. Jurnal Nominal. Volume VII Nomor 2 
[23] Samasta, A. S., Muharam, H., \& Haryanto, A. M. (2018). The Effect Of Board Of Director, Audit Committee, Institutional Ownership To Firm Value, With Firm Size, Financial Leverage, And Industrial Sector As Control Variables (Study On Listed Companies In Indonesian Stock Exchange Period 2011-2015). Jurnal Bisnis STRATEGI. Vol. 27 No. 1 Juli 2018, halaman $53-62$

[24] Setiyawati, L., Wahyudi, S., \& Mawardi, W. (2017). The Influence Of Dividend Policy, Debt Policy, Independent Commissioner, And Institutional Ownership On The Firm Value With Growth Opportunities As Moderator Variables (Study On Non-Financial Companies Listed On Idx In The Period Of Years Of 2012-2015). Jurnal Bisnis STRATEGI. Vol. 26 No. 2 Desember 2017, halaman 146 $-162$

[25] Sutrisno and Sari, L. R. (2020) 'Pengaruh Struktur Kepemilikan Terhadap Nilai Perusahaan Dengan Profitabilitas Sebagai Variabel Intervening Studi Pada Sektor Property dan Real Estate', EQUILIBRIUM : Jurnal Ilmiah Ekonomi dan Pembelajarannya, 8(2), p. 115. doi: 10.25273/equilibrium.v8i2.7109.

[26] Thanatawee, Y. (2014) Institutional Ownership and Firm Value in Thailand. Asian Journal of Business and Accounting 7(2), 2014. ISSN 1985-4064

[27] Viriyah, S. Z., Dhiana, P. and Pranaditya, A. (2018) . The Influence Mechanism Of Corporate Governance On Firm Value With Profitability As Intervening Variables (Study Manufacturing Companies Indecs 2015-2017). Journal Of Accounting. Volume 4 No. 4

[28] Wajdi, F., \& Mayangsari, S. (2019). The Role of CSR to Influence the Relationship between Institutional Ownership and Managerial Ownership on Firm Value. Research Journal of Finance and Accounting. Vol.10, No.22, $152-162$

[29] Wiranata, Y. A., \& Nugrahanti, Y, W. (2013). Pengaruh Struktur Kepemilikan Terhadap Profitabilitas Perusahaan Manufaktur di Indonesia. Jurnal Akuntansi dan Keuangan, Vol. 15, No. 1, Mei 2013, 15-26. ISSN 1411-0288 print / ISSN 2338-8137 online

[30] Yusra, I., Hadya, R., Begawati, N., Istiqomah, L., Afriyeni \& Kurniasih, N. (2019). Panel data model estimation: the effect of managerial ownership, capital structure, and company size on corporate value. IOP Conf. Series: Journal of Physics: Conf. Series 1175 (2019) 012285. doi:10.1088/1742-6596/1175/1/012285 